\title{
Experimental Research on Wastewater Reuse Technology of Industrial Circulating Cooling Water System
}

\author{
Li-Hui ZHANG ${ }^{1,2, a}$, Zhen-Fa LIU ${ }^{1,2, b, *}$ and Ru-Hui GUO ${ }^{1,2, c}$ \\ ${ }^{1}$ Institute of Energy Resources, Hebei Academy of Sciences, Shijiazhuang, China \\ ${ }^{2}$ Hebei Engineering Research Center for Water Saving in Industry, Shijiazhuang, China \\ azlhkxy@126.com, blzf6307@sina.com, 'cgrh11@tom.com \\ "Zhen-Fa LIU
}

Keywords: Wastewater reuse, Circulating cooling water, Decrease of hardness and desalination, Union technology.

\begin{abstract}
By means of decrease of hardness, neutralization and desalination union technology, the drained wastewater of industrial circulating cooling water system can be treated. The purified water quality (total hardness and calcium ion components) is greatly better than fresh water, and completely can be reused as make-up water for circulating cooling water system. The experimental results show that the ratio of wastewater reuse reached more than eighty percent, saving a large amount of fresh water, reduce waste water discharge, water saving and emissions reduction effect is obvious, and the production cost greatly reduced.
\end{abstract}

\section{Introduction}

The widespread use of water treatment agents provide strong technical support for the circulating reuse of industrial cooling water, so as to make the industrial water-saving became a reality. In recent years, water treatment agents have been greatly developed and improved, but the existing chemical agents still have some limits for water quality conditions, or the concentrated by evaporation is impossible on indefinitely. When concentration ratio of circulating cooling water system is 3.5 , there are still $28 \%$ water is drained in order to maintain the normal operation of the circulating water system. The drained circulating water can not be used again as supplementary water without water treatment, becouse of high hardness and high amount of bacteria and algae[1,2].

To meet the recycling water quality requirements, the wastewater should be treated by means of circulating cooling water wastewater reuse technology[3], and fall hard, neutralization, desalination and so on a series of processes. According to water quality characteristics of circulating water system from a chemical fiber enterprise in our province, to provide effective way for solving the problem of sewage wastewater reuse, we adopted the above methods, and sought the best experiment conditions[4].

\section{Experiment Instrument and Methods}

\section{Reagents and Experimental Instruments}

The reagents and experimental instruments used are as follows: $\mathrm{NaOH}$ (industrial grade), $\mathrm{H}_{2} \mathrm{SO}_{4}$ (industrial grade), fungicide (industrial grade), electronic balance (CP225D), precise pH instrument (pHS-3C), digit display conductivity instrument (DDS-11A), atomic absorption spectrophotometer (AA2610).

\section{Water Quality Analysis}

In this experiment, the raw water samples and wastewater samples used are taken from circulating cooling water system of a steel company blast furnace workshop is shown in Table 1. 
Table 1 Water quality of raw water samples and wastewater

\begin{tabular}{lllllllll}
\hline Items & $\begin{array}{l}\text { Total } \\
\text { hardness }\end{array}$ & $\mathrm{Ca}^{2+}$ & $\mathrm{SO}_{4}{ }^{2-}$ & $\mathrm{Cl}-$ & $\begin{array}{l}\text { Total } \\
\text { alkaloids } \\
(\mathrm{mg} / \mathrm{L})\end{array}$ & $\begin{array}{l}\text { Conductivity } \\
(\mu \mathrm{s} / \mathrm{cm})\end{array}$ & $\begin{array}{l}\text { Heterotrophic } \\
\text { bacteria } \\
(\mathrm{cfu} / \mathrm{mL})\end{array}$ & $\mathrm{pH}$ \\
\hline Raw water & 420.4 & 356.7 & 124.2 & 41.3 & 100.2 & 987.4 & 102 & 7.32 \\
Waste water & 1204.4 & 1034.9 & 372.6 & 124.5 & 293.7 & 1473 & 106 & 8.47 \\
\hline
\end{tabular}

\section{Experiment Methods}

According to the actual situation, a circulating cooling water waste water reuse test apparatus was assembled, the process flow diagram is shown in Fig.1.

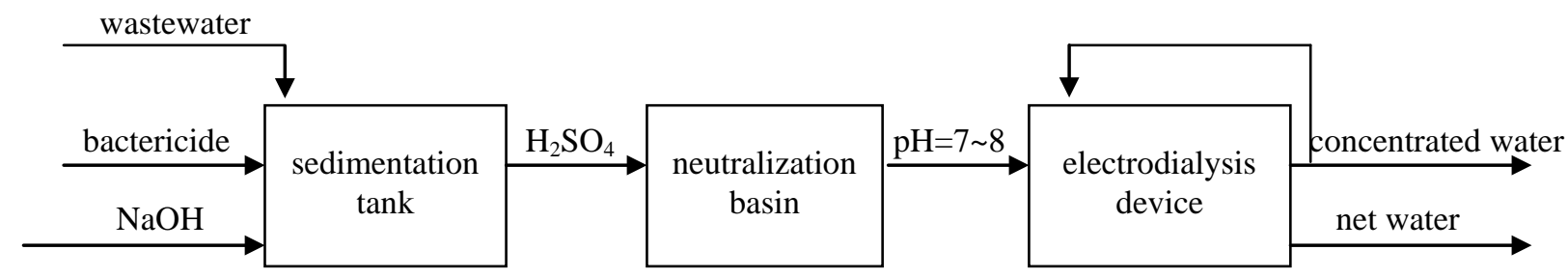

Fig.1 The process flow diagram of wastewater reuse test apparatus

Total hardness and concentration of $\mathrm{Ca}^{2+}$ are based on GB/T 15452-2009, concentration of $\mathrm{Cl}^{-}$, $\mathrm{SO}_{4}{ }^{2-}$, total alkali and heterotrophic bacteria are based on GB/T 15453-2008, GB/T 6911-2007, GB/T 15451-2006, and GB/T 14643-2009, electrical conductivity and $\mathrm{pH}$ were measured using instrument[5].

\section{Results and Discussion}

\section{Down Hard Experiment}

The circulating cooling wastewater was treated of sterilization firstly, and $\mathrm{NaOH}$ was added. The total hardness, conductivity, concentration of $\mathrm{Ca}^{2+}$, the change of heterotrophic bacteria were tested under various $\mathrm{pH}$. The results are shown in Table 2.

Table 2 The results of down hard experiment

\begin{tabular}{llllllll}
\hline $\mathrm{pH}$ & 9 & 9.5 & 10 & 10.5 & 11 & 11.5 & 12 \\
\hline $\begin{array}{l}\text { Total hardness } \\
(\mathrm{mg} / \mathrm{L})\end{array}$ & 390.8 & 224.7 & 145.1 & 98.76 & 40.38 & 20.74 & 15.84 \\
$\mathrm{Ca}^{2+}$ & 336.8 & 193.2 & 120.4 & 76.76 & 21.5 & 10.9 & 9.23 \\
$\begin{array}{l}\text { (mg/L) } \\
\begin{array}{l}\text { Conductivity } \\
(\mu \mathrm{s} / \mathrm{cm})\end{array}\end{array}$ & 1514 & 1607 & 1713 & 1842 & 2009 & 2204 & 2514 \\
$\begin{array}{l}\text { Heterotrophic } \\
\text { bacteria } \\
(\mathrm{cfu} / \mathrm{mL})\end{array}$ & $10^{2}$ & $10^{2}$ & $10^{2}$ & $10^{2}$ & $10^{2}$ & $10^{2}$ & $10^{2}$ \\
\hline
\end{tabular}

As show in Table 2, the quantity of heterotrophic bacteria decreased from $10^{6}$ to $10^{2}$ when bactericide was added. With the increase of $\mathrm{pH}$, the total hardness and concentration of $\mathrm{Ca}^{2+}$ of wastewater decreased, this is because the precipitation of $\mathrm{Ca}(\mathrm{OH})_{2}$ was generated. $\mathrm{Ca}(\mathrm{OH})_{2}$ is poorly 
soluble chemical substance, solubility product is $3.1 \times 10^{-5}$. With the increase of $\mathrm{pH}$, the conductivity and ionic concentration increased, this result in the largeness of precipitation particle and acceleration of precipitation. The increase of $\mathrm{pH}$ is helpful to precipitation of $\mathrm{Ca}^{2+}$ undoubtedly, but result in processing cost increase and subsequent processing difficulty due to the increase of ionic concentration and the dosage of $\mathrm{NaOH}$. In a comprehensive view, the $\mathrm{pH}$ value was controlled between $9.8 \sim 10$ during the precipitation separation process. When the the $\mathrm{pH}$ value was $9.8 \sim 10$, the total removal rate of hard was more than $80 \%$, the effective content of fungicide was $20 \%$ and the addition amount was $10 \mathrm{mg} / \mathrm{L}$, the concentration of $\mathrm{NaOH}$ solution was $30 \%$ and the addition amount was $0.9 \mathrm{~g} / \mathrm{L}$.

\section{Neutralization Experiment}

In order to the operation of the subsequent process, the value of $\mathrm{pH}$ of samples $\mathrm{pH}=9.5, \mathrm{pH}=10.0$, and $\mathrm{pH}=10.5$ (in Table 2) was adjusted to $9.5-10.5$ by adding $0.15 \mathrm{~g} / \mathrm{L}$ sulfuric acid $(10 \%)$. The results showed that the conductivity decreased about $20 \%$ after neutralization experiment is shown in Table 3.

Table 3 The results of neutralization experiment

\begin{tabular}{llll}
\hline Water samples & $\mathrm{pH}=9.5$ & $\mathrm{pH}=10.0$ & $\mathrm{pH}=10.5$ \\
\hline Conductivity $(\mu \mathrm{s} / \mathrm{cm})$ & 1302 & 1385 & 1408 \\
Decrease of conductivity (\%) & 19.0 & 19.1 & 23.6 \\
\hline
\end{tabular}

\section{Dynamic experiments}

Circulating cooling water discharge wastewater reuse was tested by dyamic experiment, continuous access to water treatment processes was used for a long time to run tests. The feed water was $300 \mathrm{~L} / \mathrm{h}$ according to the actual situation. The results are shown in Table 4, 5 and 6.

Table 4 The relationship of the amount of water and acid base

\begin{tabular}{lllll}
\hline $\begin{array}{l}\text { Water inflow } \\
(\mathrm{L} / \mathrm{h})\end{array}$ & $\begin{array}{l}\text { Sodium hydroxide } \\
\text { dosage }(10 \%) \\
(\mathrm{L} / \mathrm{h})\end{array}$ & $\begin{array}{l}\text { Sedimentation } \\
\text { tank } \mathrm{pH}\end{array}$ & $\begin{array}{l}\text { Acid consumption } \\
(5 \%) \\
(\mathrm{L} / \mathrm{h})\end{array}$ & $\begin{array}{l}\text { Neutralization } \\
\text { basin } \mathrm{pH}\end{array}$ \\
\hline 300 & 2.7 & 9.78 & 0.9 & 7.2 \\
\hline
\end{tabular}

Sodium hydroxide dosage and acid consumption are displayed in Table 4, in order to maintain the $\mathrm{pH}$ of sedimentation tank and neutralization basin at $300 \mathrm{~L} / \mathrm{h}$ feed water.

Table 5 The relationship water yield and water inflow

\begin{tabular}{llllll}
\hline $\begin{array}{l}\text { Water } \\
\text { inflow } \\
(\mathrm{L} / \mathrm{h})\end{array}$ & $\begin{array}{l}\text { Net water } \\
(\mathrm{L} / \mathrm{h})\end{array}$ & $\begin{array}{l}\text { Concentrated } \\
\text { water } \\
(\mathrm{L} / \mathrm{h})\end{array}$ & $\begin{array}{l}\text { Return } \\
\text { concentrated } \\
\text { water } \\
(\mathrm{L} / \mathrm{h})\end{array}$ & $\begin{array}{l}\text { Discharge } \\
\text { concentrated } \\
\text { water } \\
(\mathrm{L} / \mathrm{h})\end{array}$ & $\begin{array}{l}\text { Power } \\
\text { consumption } \\
(\mathrm{kW})\end{array}$ \\
\hline 300 & 210 & 90 & 60 & 30 & 1.2 \\
\hline
\end{tabular}

(Discharge concentrated water was outflow of water at the end of permeability desalting process, return concentrated water was a mixture of concentrated water contained the water was going to and have electroosmosis desalinate.) 
Table 6 The water quality status of net water

\begin{tabular}{llllll}
\hline $\begin{array}{l}\text { Net water } \\
(\mathrm{L} / \mathrm{h})\end{array}$ & $\begin{array}{l}\text { Total } \\
\text { hardness } \\
(\mathrm{mg} / \mathrm{L})\end{array}$ & $\begin{array}{l}\mathrm{Ca}^{2+} \\
(\mathrm{mg} / \mathrm{L})\end{array}$ & $\begin{array}{l}\text { Conductivity } \\
(\mu \mathrm{s} / \mathrm{cm})\end{array}$ & $\begin{array}{l}\text { Heterotrophic } \\
\text { bacteria } \\
(\mathrm{cfu} / \mathrm{mL})\end{array}$ & $\mathrm{pH}$ \\
\hline 210 & 37.5 & 35.8 & 620 & 0 & 7.2 \\
\hline
\end{tabular}

As shown in Table 5, when the water inflow was $300 \mathrm{~L} / \mathrm{h}$, discharge concentrated water was controled at $30 \mathrm{~L} / \mathrm{h}$, then the net water was $210 \mathrm{~L} / \mathrm{h}$, the recovery rate of circulating water was about $90 \%$. From the water quality status of net water in Table 6 , we can know the water quality was excellent, particularly total hardness and the concentration of $\mathrm{Ca}^{2+}$ were better than that of raw water, can be used as supplementary cycle water.

\section{Production test}

A circulating cooling water wastewater reuse treatment device was produced with $60 \mathrm{t} / \mathrm{h}$ processing capacity by using the exsiting circulating cooling water system of this enterprise. The conditions of production operation and water quanlity is shown in Table 7 and 8, respectively.

Table 7 Production operation conditions

\begin{tabular}{llll}
\hline $\begin{array}{l}\text { Water inflow } \\
(\mathrm{t} / \mathrm{h})\end{array}$ & $\begin{array}{l}\text { Net water } \\
(\mathrm{t} / \mathrm{h})\end{array}$ & $\begin{array}{l}\text { Discharge } \\
\text { concentrated water } \\
(\mathrm{t} / \mathrm{h})\end{array}$ & $\begin{array}{l}\text { Power } \\
\text { consumption } \\
(\mathrm{kW})\end{array}$ \\
\hline 60 & 52 & 8 & 45 \\
\hline
\end{tabular}

Table 8 Water quanlity conditions

\begin{tabular}{llllll}
\hline $\begin{array}{l}\text { Water } \\
\text { inflow } \\
(\mathrm{t} / \mathrm{h})\end{array}$ & $\begin{array}{l}\text { Total } \\
\text { hardness } \\
(\mathrm{mg} / \mathrm{L})\end{array}$ & $\begin{array}{l}\mathrm{Ca}^{2+} \\
(\mathrm{mg} / \mathrm{L})\end{array}$ & $\begin{array}{l}\text { Conductivity } \\
(\mu \mathrm{s} / \mathrm{cm})\end{array}$ & $\begin{array}{l}\text { Heterotrophic } \\
\text { bacteria } \\
(\mathrm{cfu} / \mathrm{mL})\end{array}$ & $\mathrm{pH}$ \\
\hline 52 & 36.7 & 33.2 & 610 & 0 & 7.5 \\
\hline
\end{tabular}

\section{Cost Accounting}

The cost was calculated by production test data. Relevant consumption materials are shown in Table 9.

Table 9 The consumption materials and power

\begin{tabular}{lllll}
\hline Materials & $\begin{array}{l}\mathrm{NaOH} \\
(30 \%)\end{array}$ & $\begin{array}{l}\mathrm{H}_{2} \mathrm{SO}_{4} \\
(98 \%)\end{array}$ & $\begin{array}{l}\text { Fungicide } \\
(20 \%)\end{array}$ & $\begin{array}{l}\text { Average power } \\
\text { consumption }\end{array}$ \\
\hline Market price & 600 yuan/t & 2000 yuan $/ \mathrm{t}$ & 6000 yuan $/ \mathrm{t}$ & 1.00 yuan \\
Consumption & $0.9 \mathrm{~kg}$ & $0.15 \mathrm{~kg}$ & $0.01 \mathrm{~kg}$ & 0.9 \\
$\begin{array}{l}\text { Processing } \\
\text { cost }\end{array}$ & $\begin{array}{l}0.9 \times 10^{-3} \times 600+0.15 \times 10^{-3} \times 2000+0.01 \times 10^{-3} \times 6000+0.9 \times 1.00=1.80 \\
\text { yuan }\end{array}$ & & & \\
\hline
\end{tabular}

At present, cost of water in enterprise are mostly between $4 \sim 5$ yuan/t, so the saved cost of one ton wastewater treatment can be about $2 \sim 3$ yuan. 


\section{Summary}

The sewage wastewater processing of circulating cooling water system by the fall hard, neutralization, and desalination technology is feasible. Purification water quality (total hardness and $\mathrm{Ca}^{2+}$ concentration) after traetment ia greatly better than that of the fresh water, completely can be used again as make-up water for circulating cooling water system.

The production test results of enterprise show that reuse rate of sewage waste water can reach $86 \%$, the processing cost is 1.80 yuan/t, water cost saved is about $2 \sim 3$ yuan/t, production cost is decreased, and economic and social benefit are remarkable.

\section{Acknowledgement}

This research was financially supported by the Science and Technology Plan Projects of Hebei Province (15273103D).

\section{References}

[1] Bensheng Zhou, Industrial Water Treatment Technology, second ed., Chemical industry press, 14-30, 2002. In Chinese.

[2] Shouyin Tang, Wastewater Treatment Engineering, second ed., Chemical industry press, 40-55, 2004. In Chinese.

[3] X. Y. Zhao, Y. J. Wang, H. Q. Zhao, The Commercial Reuse of Industrial Wastewater for Recirculating Cooling Water, Industrial water \& Waste water, 31 (1) : 32-34, 2000. In Chinese.

[4] H. B. Li, J. H. Wei, Researches and Experiments of the Application of Purified Effluent in the Power Plant to Circulating Supplementary Water, Industrial Water Treatment, 23 (10) : 62-63, 2003. In Chinese.

[5] Chemical industry standard assembly - water quality analysis methods of water use in industrial water treatment agent, China standard publishing house, 2010. In Chinese. 